\title{
AN OBVERVATIONAL STUDY ON A BATAK ENGLISH LEARNER IN CONSONANT SOUND PRODUCTION
}

\author{
Yuliyanto Sabat \\ STKIP PGRI Sidoarjo \\ sabatkeren@gmail.com
}

\begin{abstract}
This article reports on the result of a study aiming to describe what difficulties experienced by Batak English learner in consonant sound production and the factors which cause him difficult to produce those sounds. The study was conducted to Batak English learner who is still taking pronunciation course in the first semester in the English study program at one of private universities in East Java, Indonesia. The study used a qualitative case study research design with the data collected from the analysis of students' English consonants production and interview. The findings showed that all sounds of voiceless dental frecative consonant $[\theta]$ in initial position were pronounced into voiceless alveolar stop consonant $[\mathrm{t}]$ while the research participant was pronouncing the sound of voiced dental frecative consonant [ð], he mispronounced the sound into voiced alveolar stop consonant [d] in both initial and medial position. The sound of voiced alveolar affricate consonants [dz] was pronounced appropriately while voiceless alveolar affricate consonant was pronounced into voiceless alveolar fricative consonant [s]. The factors which cause the participant find it difficult to learn pronunciation were afraid of making mistakes, limited time to repeat it at home, and habit.
\end{abstract}

Keywords: English Consonant, Students' difficulties, Sound Productions.

\section{INTRODUCTION}

One of the most important elements in achieving speech intelligibility is pronunciation. The type of English that we speak does not matter very much as far as we speak in an intelligible way (Wei and Zhou, 2002:1). Therefore, pronunciation takes a great role in a communication. Believe it or not, many native speakers sometimes feel uncomfortable while they are talking to non native speakers whose pronunciation is poor. According to Morley (in Renandya, 1999: 61), "In a conversation with a non-native speaker who has poor intelligibility, many native speakers report that they experience very uncomfortable apprehensive feelings as the interaction proceeds. Even though they seem to 
understand what the second speaker is problem in learning pronunciation saying at the moment, they feel a (Bell,1995). Therefore, one of the continuous undercurrent of anxiety, afraid alternative ways to help students improve that communication will break down as their English pronunciation is to know the the interaction moves along.

difference the learners' first language and

English as a foreign language the target language. According to Nasr learner, particularly Indonesian learners (1978:30) the followings are kinds of find it difficult to learn pronunciation English consonants completed with the especially in consonant production ways they are produced.

because the difference between first language and second language is a

English Consonants

\begin{tabular}{|c|c|c|c|c|c|c|c|c|}
\hline $\begin{array}{l}\text { PoA } \\
\text { MoA }\end{array}$ & Bilabial & $\begin{array}{l}\text { Labio- } \\
\text { dental }\end{array}$ & dental & Alveolar & $\begin{array}{c}\text { Post } \\
\text { alveolar }\end{array}$ & palatal & Velar & Glottal \\
\hline \multirow[t]{2}{*}{ Stop } & $\mathrm{p}$ & & & $\mathrm{t}$ & & & $\mathrm{k}$ & \\
\hline & $\mathrm{b}$ & & & $\mathrm{d}$ & & & $\mathrm{g}$ & \\
\hline Affricates & & & & $\begin{array}{l}\mathrm{t} \int \\
\mathrm{d} 3\end{array}$ & & & & \\
\hline \multirow[t]{2}{*}{ Fricatives } & & $\mathrm{f}$ & $\theta$ & $\mathrm{S}$ & $r$ & $\int$ & & $\mathrm{h}$ \\
\hline & & $\mathrm{v}$ & ð & $\mathrm{z}$ & & 3 & & \\
\hline Nasals & $\mathrm{m}$ & & & $\mathrm{n}$ & & & $\eta$ & \\
\hline Laterals & & & & 1 & & & & \\
\hline $\begin{array}{c}\text { Semi- } \\
\text { vowels }\end{array}$ & $\mathrm{W}$ & & & & & $\mathrm{j}$ & & \\
\hline
\end{tabular}

According to Dartowidjojo (2003: 35) the followings are the Indonesia Consonants.

Indonesian Consonants

\begin{tabular}{|l|c|c|c|c|c|c|}
\hline $\begin{array}{l}\text { Titik Art. } \\
\text { Cara Art }\end{array}$ & $\begin{array}{l}\text { Bi- } \\
\text { labial }\end{array}$ & $\begin{array}{l}\text { Labio- } \\
\text { dental }\end{array}$ & Dental & Palatal & Velar & Glotal \\
\hline Plosif & P b & & t d & & k g & \\
\hline Frikatif & & f v & s z & S & x & h \\
\hline Afrikat & & & & $\mathbf{c ~ j}$ & & \\
\hline Nasal & $\mathbf{m}$ & & $\mathbf{n}$ & $\mathbf{n}$ & & g \\
\hline Getar & & & $\mathbf{r}$ & & & \\
\hline Lateral & & & $\mathbf{l}$ & & & \\
\hline Semivokal & $\mathbf{w}$ & & & $\mathbf{y}$ & & \\
\hline
\end{tabular}

Raoan 1 Knnsonan Rahasa Indnnesia 
Based on two comparisons above, it can be seen that Indonesian does not have sounds such as $[\theta],[ð],[3],[\mathrm{d} 3]$, and [t $\left.\int\right]$. However, the researcher finds an interesting phenomenon while teaching pronunciation subject in a class. Although there are some English consonants do not exist Indonesian, some indonesian students can pronounce it appropriately and some others can not.

The class consits of students which come various backgrounds and ethnicities. The hardest experience seems encountered by students from Batak as the researcher observed the learning process he could not pronounce the English words appropriately all together with his friends. He even called personally the students to be taught individually but he still found it difficult. Therefore, this research focuses on the difficulties experienced by Batak learner and the factors which cause him difficult to learn pronounciation. In addition, the researcher limits his study on the discreed sounds which do not exist in Indonesian.

\section{Statements of the problem}

What English consonant sounds does Batak learner frequently mispronounce?
What factors which make Batak learner find it difficult to pronounce those sounds?

\section{RESEARCH METHODOLOGY}

This research used a case study research method because it focuses on a single unit and is anchored in real life (Carroll, 2010:452). In more specific, type of this case study is observational as this research tends to study a particular entity such a class within a school (McMillan (2008:288). The researcher would like to search student's difficulties in learning pronunciation particularly English consonant and at the same time he would also want to search the factors causing the problems. The participant of the research is a student from Batak (One of ethnics in Indonesia) in the first semester who is taking pronunciation subject.

In conducting this research, the researcher formulated a certain research design as this is the researcher's plan of how to proceed to gain an understanding of some group or phenomenon in its context (Glesne and Peshkin, 1992: 426). Below is the research design. 


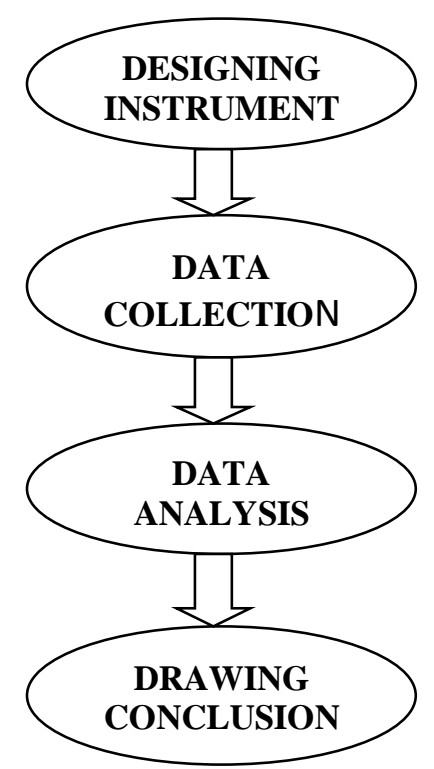

The steps which will be taken by the researcher in taking data are 1) designing the instrument of the research; 2) data collection; 3) data analysis; 4) drawing conclusion in relation to the research questions formulated.
The first step of taking the data is by designing the instrument. Basically the primary instrument for data collection in qualitative research is the researcher himself (Glesne and Peshkin, 1992: 421). However, the researcher still needs other supporting instruments such as test and interview. The test will be in form of listed words to be pronounced. The following are the words that the students are supposed to pronounce. The words are divided based on the positions of the sounds. They are initial, middle and final positions. Here are the words that the participant should pronounce.

\begin{tabular}{llll}
\hline \multicolumn{1}{c}{ POSITION } & INITIAL & MEDIAL & FINAL \\
\hline SOUNDS & & & \\
\hline$[\theta]$ & 1) Thank & 1) Athletes & 1) Bath \\
& 2) Three & 2) Ethnicity & 2) Breath \\
& 3) Thread & 3) Rethinking & 3) Cloth \\
& 4) Thin & 4) Authored & 4) Tooth \\
& 5) Thrill & 5) Authors & 5) Sooth \\
\hline$[ð]$ & 1) There & 1) Father & 1) Bathe \\
& 2) Then & 2) Brother & 2) Breathe \\
& 3) Thus & 3) Leather & 3) Clothe \\
& 4) Though & 4) Mother & 4) Loathe \\
& 5) Than & 5) Weather & 5) Soothe \\
\hline$[d 3]$ & 1) Job & 1) Agent & 1) Spillage \\
& 2) Judge & 2) Adjust & 2) Orange \\
& 3) Join & 3) Adjoin & 3) Hajj \\
& 4) Joke & 4) Angels & 4) Judge \\
& 5) Jump & 5) Injury & 5) raj \\
\hline$\left[\int\right]$ & 1) Shade & 1) Actions & 1) Establish \\
& 2) Shadow & 2) Adoption & 2) British \\
& 3) Shark & 3) Examination & 3) English \\
\hline
\end{tabular}


4) Shape

4) Exception

4) Tush

5) Shake

5) allocation

5) Quiche

https://www.learningfundamentals.com/words/position.php

In addition to the listed words pronounced by the participants, the researcher also used the other supporting instrument to collect the data such as interview. This instrument is aimed to achieve an in depth-description on the answer of formulated problems. There are many types of interview and he chose unstructured interview in his research as suggested by Lincoln and Guba (1985: 269) that "If the researcher is not aware on what he does not know and relies on the respondents to tell him, unstructured interview is useful for such research".

The second step is data collection. In this step, the researcher administers the test to the participants of the research. They are provided with several words consisting of some English consonants as it has been explained before. They are to read the words for three times and their voices are recorded with the assumption twice they practice pronouncing the words and the last chance of pronouncing is recorded as the data which will be analyzed. This step is aimed to identify students' mistake in pronunciation.
The third step is data analysis. The data got from the test are played again through the audio player. The researcher listens to the pronunciation produced by the students. While listening, he pays attention carefully on the text of the words. In this process, the researcher decides whether the students mispronounce the words, what English consonant sounds are frequently mispronounced and it what position of sounds that they frequently make mistake. After all, he will do in-depth interview to the participants to elaborate more the reasons why they make mistakes. This interview is aimed to answer the second statement of the problems.

The last step taken in this research is drawing conclusions. Drawing conclusion will be based on the data which have been analyzed to describe the sounds which are frequently mispronounced by participants and the factors which make them mispronounce the words. 


\section{RESULT}

The sound of voiceless dental frecative consonant $[\theta]$ is mostly pronounced into voiceless alveolar stop consonant $[\mathrm{t}]$ in initial and medial position while the sound of voiceless dental frecative consonant $[\theta]$ is pronounced into voiced alveolar stop consonant $[\mathrm{d}]$ in some words positioned in final. In detail it can be described that all voiceless dental frecative consonants $[\theta]$ in initial position are pronounced into [t], two sounds of $[\theta]$ in medial position are pronounced [d] while others pronounced into voiceless alveolar stop consonant [t] , and all sounds of $[\theta]$ in final position are pronounced in voiced alveolar stop consonant [d]. The following table shows how a research participant pronounces the decreed sound.

Table 1

Sound production of $[\theta]$ in initial, medial, and final position

\begin{tabular}{|c|c|c|c|c|c|c|c|c|}
\hline INITIAL & Phonetics & Participant & MEDIAL & Phonetics & Participant & FINAL & Phonetics & Participant \\
\hline 1) Thank & 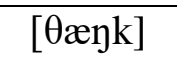 & [tæyk] & 1) Athletes & [æ0li:t] & [ætli:t] & 1) Bath & {$[\mathrm{bæ} \theta]$} & [bæd] \\
\hline 2) Three & [өri:] & [tri:] & $\begin{array}{c}\text { 2) } \\
\text { Ethnicity }\end{array}$ & [e $\theta$ nisiti] & [etnisiti] & $\begin{array}{c}\text { 2) } \\
\text { Breath }\end{array}$ & [bre $\theta]$ & [bred] \\
\hline $\begin{array}{c}\text { 3) } \\
\text { Thread }\end{array}$ & [Ored] & [tred] & $\begin{array}{c}\text { 3) } \\
\text { Rethinking }\end{array}$ & 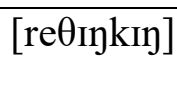 & [retınkin] & $\begin{array}{c}\text { 3) } \\
\text { Cloth }\end{array}$ & [kla: $\theta]$ & [kla:d] \\
\hline 4) Thin & [Oin] & [tin] & $\begin{array}{c}\text { 4) } \\
\text { Authored }\end{array}$ & [o:.Өərd] & [o:.dər] & $\begin{array}{c}\text { 4) } \\
\text { Tooth }\end{array}$ & [tu: $\theta$ ] & [tu: d] \\
\hline 5) Thrill & [Oril] & [tril] & 5) Authors & [0:.Өərs] & [o:.dors] & $\begin{array}{c}5) \\
\text { Sooth }\end{array}$ & [su:ð] & [su:d] \\
\hline
\end{tabular}

The above table shows the participant's mistake in producing voiceless dental frecative consonants $[\theta]$ whether in initial, medial, and final position. Most mistakes made by the participant is changing the sound of voiceless dental frecative consonant $[\theta]$ into voiceless alveolar stop consonant $[\mathrm{t}]$ in initial position and medila while all sounds of $[\theta]$ in final position are pronounced in voiced alveolar stop consonant $[\mathrm{d}]$.
While the research participant was pronouncing the sound of voiced dental frecative consonant [ð], he pronounced the sounds into voiced alveolar stop consonant $[\mathrm{d}]$ in initial and medial position. While two sounds of voiced dental frecative consonant [ð] in final position were pronounced into voiceless alveolar stop consonant $[\mathrm{t}]$ and rests were pronounced into [d]. The following table shows the common mistakes made by the participant when producing the sounds. 
Table 2

Sound Production of [ð] in initial position, medial, final postion.

\begin{tabular}{|c|c|c|c|c|c|c|c|c|}
\hline INITIAL & Phonetics & Participant & MEDIAL & Phonetics & Participant & FINAL & Phonetics & Participant \\
\hline 1) There & [ðеə] & [deə] & Father & [fa:.ðə ] & [fa:.do ] & Bathe & [beıð] & [beit] \\
\hline 2) Then & [ðеn] & [den] & Brother & [br^ðə] & [brıdə] & Breathe & [bri:ð] & [bri:t] \\
\hline 3) Thus & [ð $\Lambda \mathrm{s}]$ & {$[\mathrm{d} \Lambda \mathrm{s}]$} & Leather & [leðə] & [ledə] & Clothe & [klov:ð] & [klov:d] \\
\hline 4) Though & [ðо৩] & [dov] & Mother & [m^ðə] & [m^də] & Loathe & [lov:ð] & [lov:d] \\
\hline 5) Than & [ðæn] & [den] & Weather & [weðə] & [wedo] & Soothe & [su: ð] & [su: d] \\
\hline
\end{tabular}

The less mistakes happen to voiced

alveolar consonant [dz]. The research

participant pronounced this sound

or final. He only made mistakes in

pronouncing these two words Orange

and raj placed in final position.

appropriately whether in initial, medial,

Table 3

Sound Production of [dz] in initial position, medial, final position.

INITIAL Phonetics Participant MEDIAL Phonetics Participant FINAL Phonetics Participant

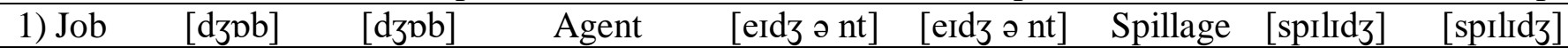

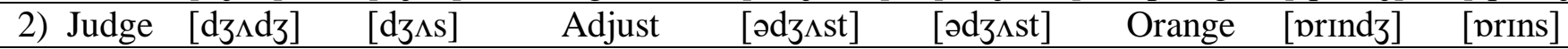

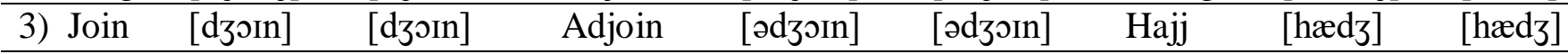

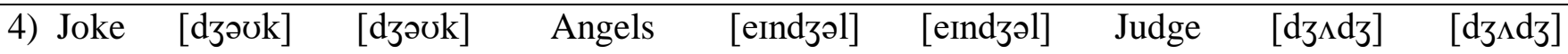

5) Jump [dz^mp] [dz^mp] Injury [Indzə ri] [Indzə ri] raj [ra: d3] [ra: s]

The last sound is voiceless except the word quiche [ki:f] was

palatal frecative [S]. He pronounced all pronounced into [ki:k] ([S] was

[J] sounds into voiceless alveolar

frecative consonant $[\mathrm{s}]$ in all positions pronounced into $[\mathrm{k}]$. The following table gives the details.

Table 4

Sound Production of [J] in initial position, medial, final position.

\begin{tabular}{|c|c|c|c|c|c|c|c|c|}
\hline INITIAL & Phonetics & Participant & MEDIAL & Phonetics & Participant & FINAL & Phonetics & Participant \\
\hline 1) Shade & [ $\mathrm{e}$ eId] & [seId] & Action & [æk $\int$ on] & [æks ən] & Establish & [istæblif] & [Istæblis] \\
\hline 2) Shadow & 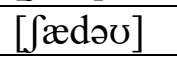 & [sædəひ] & Adoption & [ədpp $\left.\int \partial \mathrm{n}\right]$ & [ədopsə n] & British & [britif] & [britis] \\
\hline 3) Shark & 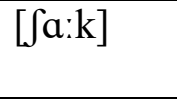 & [sa:k] & Examination & $\begin{array}{l}\text { [IgzæmineI. } \\
\text { ə n] }\end{array}$ & $\begin{array}{l}\text { [IgzæmineIsə } \\
\mathrm{n}]\end{array}$ & English & [Inglif] & [Inglis] \\
\hline 4) Shape & [ & [seip] & Exception & 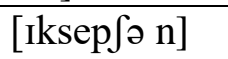 & [Iksepsə n] & Tush & {$\left[\mathrm{t} \Lambda \int\right]$} & {$[\mathrm{t} \Lambda \mathrm{s}]$} \\
\hline 5) Shake & 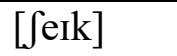 & [seIk] & Allocation & [æləkeıfə n] & [æləkeısə n] & Quiche & [ki:S] & [ki:k] \\
\hline
\end{tabular}


Based on the result of interview, it was found out that there were several reasons why the research participant made mistakes in producing English sound consonant. Those reasons were 1) the research participant was afraid of making mistakes while learning pronounciation and afraid of being laughed by his friends if he mispronounced the words; 2) he has limited time to repeat the lesson at home. It was found out that the research participant was a worker not a pure student. Therefore, he has very limited time to repeat and practice the lesson at home; and 3) it is a matter of habit. He confessed that he was not accustomed to practicing pronouncing English words since he was in senior high school. Therefore, while he was prepared to pronounce the English words his tongue seems clumsy to do so.

\section{REFERENCES}

Bell, J. S. (1995). The relationship between L1 \& L2 Literacy: Some complicating factors. TESOL Quarterly, 29(4), 687-704. http://dx.doi.org/10.2307/3588170

Carroll, L. (2010). Types of qualitative research. USA: Wadsworth

Glesne, C \& Peshkin, A. (1992). Becoming qualitative resesarcher. White Plains, NY: Longman.

Lincoln,Y.S and Guba, E.G.(1985). Naturalistic inquiry. Beverly Hills:Sage Publication

McMillan, J. H. (2008). Eduacational Research: Fundementals for the Consumer. The United States of America: Pearson Educaction, Inc.

Nashr, R. T. (1978). The Essential of Linguistic Science. England: Longman Group Ltd.

Wei, et al. (2002). Insights into English Pronunciation Problems of Thai Students. Reports Research (143):Thailand

C.W.Renandya. (1999). Language Teaching: New Insights for The Language Teacher. SEOMEO , 5679. 